REFLEKSI HUKUM

Jurnal Ilmu Hukum
p-ISSN 2541-4984 | e-ISSN 2541-5417

Volume 2 Nomor 2, April 2018, Halaman 181 - 192

DOI: https://doi.org/10.24246/jrh.2018.v2.i2.p181-192

Open access at: http:/ / ejournal.uksw.edu/refleksihukum

Penerbit: Fakultas Hukum Universitas Kristen Satya Wacana

\title{
KEBIJAKAN HUKUM PIDANA DALAM UPAYA MENANGGULANGI LGBT (LESBIAN, GAY, BISEKSUAL, DAN TRANSGENDER) BERBASIS NILAI-NILAI PANCASILA
}

\author{
Nila Arzaqi \\ Magister Ilmu Hukum Universitas Diponegoro \\ Korespondensi: nilaarzaqinilzaq@gmail.com
}

\begin{abstract}
Abstrak
Ada sementara pandangan bahwa keberadaan kelompok LGBT di Indonesia telah mengganggu nilai-nilai Pancasila, terutama nilai ke-Tuhanan serta nilai moral dalam kehidupan masyarakat Indonesia. Kebijakan hukum pidana dapat menjadi salah satu upaya dalam merespons keberadaan kelompok LGBT ini, dengan membuat serta merumuskan peraturan baik dalam KUHP, Undang-Undang Pornografi maupun peraturan perundangan yang lain. Kebijakan hukum pidana dalam upaya merespons keberadaan kelompok LGBT ini juga dapat dilihat sebagai upaya pembaharuan hukum pidana terkait dengan tindakan-tindakan yang dianggap melanggar Pancasila. Namun, upaya tersebut perlu dibarengi dengan kajian perbandingan hukum agar dapat dirumuskan peraturan perundang-undangan yang baik dalam merespons keberadaan LGBT.
\end{abstract}

Kata Kunci: Kebijakan, Hukum Pidana, LGBT.

\begin{abstract}
There is a view that the existence of LGBT groups in Indonesia has violated the values of Pancasila, especially the belief in the supreme God and also violated the moral values of the Indonesian people. The criminal law policy can be employed as an effort in addressing the existence of LGBT groups, by making and formulating legislations in the Criminal Code, Pornography Law and other relevant laws and regulations. The criminal law policy in addressing the existence of LGBT groups can also be seen as an effort to reform criminal law related to actions that are considered as violations of Pancasila. However, these efforts need to be accompanied by a comparative law study so that the needed legislation can be formulated well in responding to LGBT existence.
\end{abstract}

Keywords: Criminal law policy, Criminal Law, LGBT. 


\section{PENDAHULUAN}

Indonesia lahir dengan ideologi Pancasila, yang diambil dari jiwa dan nilai-nilai yang hidup dalam masyarakat bangsa Indonesia. Indonesia hidup dalam keberagaman baik agama, suku, budaya, bahasa, dan pandangan yang semuanya menyatu dalam satu pandangan Pancasila. Pancasila sendiri pada hakikatnya merupakan suatu kekayaan bangsa oleh karena bisa menjadi panutan nilai moral, etis, dan spiritual. ${ }^{1}$ Sebagai pedoman, Pancasila telah memiliki 5 prinsip lengkap yaitu Ketuhanan (theisme), kemanusiaan (humanisme), kebangsaan (demokrasi), dan keadilan sosial (sosialisme). Fungsi Pancasila sebagai sebuah pedoman juga mengandung arti bahwa setiap perbuatan tidak boleh bertentangan dengan apa yang sudah diamanatkan dalam prinsip-prinsip Pancasila tersebut.

Nilai kemanusiaan atau yang modern disebut dengan hak asasi manusia (selanjutnya disebut HAM) sebagai salah satu nilai yang fundamental dimiliki setiap manusia. HAM adalah hak yang alamiah yang dimiliki manusia yang sudah melekat pada dirinya sejak manusia terlahir ke dunia. Hak alamiah ini mendahului posisi legal, kultural, ekonomi dan sosial manusia dalam komunitasnya, karena hak ini diberikan oleh kekuasaan adi duniawi, yaitu Tuhan YME. ${ }^{2}$ Hak ini sifatnya sangat mendasar (fundamental) bagi hidup dan kehidupan manusia dan merupakan hak kodrati yang tidak bisa terlepas dari dan dalam kehidupan manusia. ${ }^{3}$

Namun HAM yang datang setelah adanya perubahan dalam amandemen Undang-undang Dasar Negara Republik Indonesia Tahun 1945 ini, tidak bisa dijadikan tempat berlindung apabila perbuatan yang dilakukan bertentangan dengan nilai-nilai Pancasila dan moral masyarakat. Dalam konteks kekiniankhususnya pasca reformasi-Pancasila sangat jarang dibicarakan, khususnya dalam hubungannya dengan ilmu hukum. ${ }^{4}$ Banyak perbuatan yang menyangkut moralitas di masyarakat Indonesia sekarang ini yang perlu di benahi dengan dengan penegakan hukumnya secara benar mengingat akibat negatif atau hukum yang timbul sangat banyak. ${ }^{5}$

Kehadiran kelompok lesbian, gay, biseksual, dan trangender (LGBT) di Indonesia pada kenyataannya telah menimbulkan kegaduhan di tengah masyarakat Indonesia, karena telah dianggap sebagai perlawanan terhadap agama, kodrat, dan nilai yang hidup dalam masyarakat Indonesia yang tidak pernah memperbolehkan perbuatan yang demikian. Perbuatan LGBT adalah perbuatan yang sangat melanggar

1 Christina Maya Indah Susilowati, 'Pancasila Sebagai Sumber Segaka Sumber Hukum Dan Kekerasan Atas Nama Agama Di Indonesia' (2016) 45 Jurnal Masalah-Masalah Hukum 1, 2.

2 Rahayu, Hukum Hak Asasi Manusia (Badan Penerbit Universitas Diponegoro 2015$) 5$.

3 Masyhur Effendi, Dimensi Dan Dinamika Hak Asasi Manusia Dalam Hukum Nasional Dan Internasional (Ghalia Indonesia 1994) 3.

4 Tongat, 'Pancasila Sebagai Dasar Falsafah Negara dan Makna Filosofinya Dalam Pembaharuan Hukum Pidana Nasional' ( 2012) 41 Jurnal Masalah-Masalah Hukum 1, 1.

5 Eko Soponyono, 'Kebijakan Kriminalisasi "Kumpul Kebo", Dalam Pembangunan Hukum Pidana Indonesia,’ (2013) 42 Jurnal Masalah-Masalah Hukum 1, 2. 
aturan agama dan nilai kehidupan yang religius di dalam masyarakat Indonesia.

Istilah "kebijakan" dalam tulisan ini diambil dari istilah "policy" (Inggris) atau "politiek" (Belanda). Bertolak dari kedua istilah asing ini, maka istilah "kebijakan hukum pidana" dapat pula disebut dengan istilah "politik hukum pidana". ${ }^{6}$ Maka politik hukum pidana mengandung arti, bagaimana mengusahakan atau membuat dan merumuskan suatu perundangundangan pidana yang baik. ${ }^{7}$

Kebijakan hukum pidana untuk membuat suatu peraturan dalam merespons LGBT didasarkan pada kenyataan bahwa LGBT dianggap sebagai penyimpangan terhadap nilai ketuhanan, kodrat, dan serta moral. Permasalahan yang dianalisis dalam tulisan ini adalah tentang bagaimana kebijakan hukum pidana dalam upaya merespons LGBT dengan berbasis pada nilai-nilai Pancasila?

\section{PEMBAHASAN}

\section{Nilai Ketuhanan Yang Maha Esa Dalam Pancasila}

Pancasila merupakan $\begin{array}{r}\text { sumber } \\ \text { segala sumber hukum negara. }\end{array}$
Penempatan Pancasila sebagai sumber
segala sumber hukum negara sesuai
dengan Pembukaan UUD 1945 alinea
keempat, yaitu Ke-Tuhanan Yang Maha
Esa, Kemanusiaan yang adil dan

beradab, Persatuan Indonesia, Kerakyatan yang dipimpin oleh Hikmat Kebijaksanaan Dalam Permusyawaratan Perwakilan, dan Keadilan Sosial bagi seluruh Rakyat Indonesia. Semua isi Pancasila tersebut di diuraikan kembali dalam bentuk hukum lain yang berdasar pula pada UUD 1945 yang memiliki tujuan. Tujuan hukum yang merupakan bagian yang tidak terpisahkan dari tujuan bernegara sebagaimana tercantum dalam Pancasila UUD 1945 yang sekaligus juga merupakan perwujudan dari sila-sila Pancasila. ${ }^{9}$ Pancasila sebagai falsafah hukum indonesia harus selalu dikembangkan sejalan dengan nilai-nilai yang hidup dalam masyarakat Indonesia yang ada dalam setiap butirbutir Pancasila.

Pancasila adalah gambaran jiwa dan nilai masyarakat, yang menjadikan persatuan dan kesatuan bangsa dengan menciptakan kerukunan hidup serta ketentraman keberlangsungan hidup berbangsa bernegara. Pancasila menjadi simbol serta acuan dalam berkehidupan yang diisi dengan nilai-nilai fundamental yang tidak bisa dirubah dan ditentang oleh kebudayaan manapun yang datang. Pancasila memiliki nilai-nilai keseimbangan yang berasal dari jiwa bangsa Indonesia, yang mana nilai tersebut saling berhubungan dan nilai memiliki nilai tertinggi yang tidak boleh ditentang dan dilanggar

6 Barda Nawawi Arief, Bunga Rampai Kebijakan Hukum Pidana Perkembangan Penyusunan Konsep KUHP Baru (Prenada Media 2014) 26.

7 Ibid.

8 Teguh Prasetyo, Sistem Hukum Pancasila (Sistem, Sistem Hukum dan Pembentukan Peraturan Perundang-undangan di Indonesia, Perspektif Teori Keadilan Bermartabad (Nusa Media 2016) 43.

9 Barda Nawawi Arief, Kumpulan Hasil Seminar Hukum Nasional Ke I s/d IX dan Konvensi Hukum Nasional 2008 Tentang Undang-Undang Dasar 1945 Sebagai Landasan Konstitusional Grand Design Sistem dan Politik Hukum Nasional (Badan Penerbit Universitas Diponegoro 2016) 77. 
yaitu nilai Ketuhanan. Tiga pilar/nilai keseimbangan Pancasila, yaitu:10

1. Berorientasi pada nilai-nilai "KeTuhanan" (bermoral religius);

2. Berorientasi pada nilai-nilai "kemanusiaan" (humanistik); dan

3. Berorientasi pada nilai-nilai "Kemasyarakatan" (nasionalistik; demokratik; berkeadilan sosial).

Pengembangan filsafat hukum nasional sebagai harus diarahkan menjadi filsafat hukum Pancasila. Pancasila sebagai dasar negara yang juga merupakan dasar falsafah hukum nasional mempunyai sifat imperatif yang tidak saja dijadikan dasar dan arahan pengembangan filsafat hukum nasional kita, melainkan sekaligus juga menjadi acuan dalam menyusun, membina, dan mengembangkan filsafat hukum yang konsisten dan relevan dengan nilai-nilai Pancasila itu sendiri. ${ }^{11}$ Adanya nilai ke-Tuhanan juga membuat apapun yang kita lakukan haruslah berasal dari tuntunan Tuhan dan tidak boleh bertentangan dengan apa yang sudah Tuhan perintahkan.

Nilai ke-Tuhanan adalah nilai yang suci dan wajib dijaga di Indonesia. Indonesia sebagai negara berkeTuhanan tidak boleh memiliki perilaku dan perbuatan yang bertentangan dengan apa yang Tuhan kehendaki yang sudah tertulis dalam kitab suci agama masing-masing. Namun pada perkembangan zaman nilai-nilai kesucian ke-Tuhanan ini seperti terkikis akibat perbuatan-perbuatan yang dilarang dan bertentangan dengan ketetapan Tuhan, salah satunya adalah perbuatan LGBT.

Kitab suci Al-Qur'an sangat menjaga nilai ke-Tuhanan Pancasila dari perbuatan LGBT. Al-Qur'an dengan keras melakukan pelarangan terhadap perbuatan LGBT tersebut. Al-Qur'an sebagai firman Tuhan Yang Maha Esa melarang serta menghukum perbuatan kaum gay pada masa Nabi Luth a.s. Perbuatan tersebut adalah perbuatan gay pertama kali dilakukan yang sangat diharamkan dan sangat menjijikkan atau keji karena itu termasuk perbuatan zalim yang melanggar kodrat manusia sebagai umat yang berpasangpasangan. Dalam surat Al-Ankabut ayat 28 terdapat seruan larangan terhadap kaum gay yang berarti demikian:

..."dan (ingatlah) ketika Luth berkata kepada kaumnya, "kamu benar-benar melakukan perbuatan yang sangat keji (homoseksual) yang belum pernah dilakukan oleh seorangpun dari umatumat sebelum kamu".

Serupa dengan surat Al-Ankabut terdapat pula seruan larangan dari Nabi Luth as terhadap kaumnya di surat AlA'raf ayat 80 yang berarti:

..."dan (kami juga telah mengutus) Luth, ketika dia berkata kepada kaumnya, "mengapa kamu melakukan perbuatan keji, yang belum pernah dilakukan oleh seorangpun sebelum kamu (di dunia ini)".

Dalam lanjutan ayat ke 84 terdapat hukuman yang diberikan terhadap kaum Nabi Luth as yang melakukan perbuatan homoseksual tersebut, yang berarti:

10 Barda Nawawi Arief, Pembangunan Sistem Hukum Nasional (Indonesia), (Penerbit Pustaka Magister 2015) 12 .

11 Ibid, 78 . 
..."Dan kami hujani mereka dengan hujan (batu). Maka perhatikanlah bagaimana kesudahan orang yang berbuat dosa itu".

Dalam ketiga ayat tersebut terlihat Al-Qur'an sebagai salah satu Kitab suci agama yang ada di Indonesia, namun juga tidak hanya dalam agama islam tetapi agama lain seperti kristenpun juga melarang perbuatan tersebut yang termuat dalam kisah Nabi Lot di dalam Alkitab. Agama di Indonesia sangat menjaga nilai-nilai ke-Tuhanan dalam Pancasila yang seharusnya tidak boleh ditentang baik atas nama HAM sekalipun. Karena HAM yang melindungi LGBT adalah faham HAM universal yang dianut negara-negara barat, sedangkan Indonesia memiliki HAM yang Pancasila dan telah memiliki nilai-nilai keseimbangan. LGBT adalah budaya barat yang sangat bertentangan atau menjadi budaya tandingan di Indonesia, karena telah bertentangan dengan nilai-nilai ketuhanan dalam Pancasila.

\section{Kebijakan Hukum Pidana dalam Upaya Menanggulangi LGBT}

Hukum pidana Indonesia adalah hukum pidana yang diwariskan oleh hukum pidana kolonial yaitu warisan dari Negara Belanda selaku penjajah Indonesia. Ini dapat dilihat dari penggunaan hukum yang selama ini masih dipergunakan oleh masyarakat Indonesia dengan KUHP yang bukan berasal dari nilai-nilai yang hidup dalam masyarakat Indonesia. Indonesia sudah berusaha melakukan pembaharuan hukum pidana dengan membuat KUHP Nasional yang berlandaskan nilai-nilai yang hidup dengan Pancasila. KUHP selama ini hanya berasal dari nilai-nilai yang ada dan hidup dalam bangsa Belanda yang banyak tidak sesuai dengan nilai yang hiduo dalam masyarakat Indonesia.

KUHP (WvS) yang selama ini diajarkan bukan hukum pidana yang memang berasal, berakar atau bersumber dari pandangan/konsep nilai-nilai dasar ("grundnorm") dan kenyataan (sosio-politik, sosio-ekonomi dan sosio-budaya) yang hidup dalam masyarakat Indonesia sendiri. ${ }^{12}$ Oleh karenanya, Indonesia sebagai bangsa yang merdeka seharusnya telah memiliki KUHP Nasional yang sudah berasal dari nilai-nilai yang hidup dalam masyarakat yang diambil dari Pancasila dan UUD NRI 1945. Telah tiba saatnya untuk merombak tata hukum pidana dan hukum pidana yang masih berpijak pada asas-asas dan dasar-dasar yang berasal dari zaman kolonial dan menggantinya dengan tata hukum pidana dan hukum pidana Indonesia, yang asas-asas dan dasar pokoknya berdasarkan dan berlandaskan Pancasila dan Undang-Undang Dasar Negara Republik Indonesia Tahun 1945. 13

Pembaharuan hukum pidana ini dimulai dengan politik hukum pidana atau kebijakan hukum pidana yang mengarahkan peraturan-peraturan hukum pidana yang sesuai dengan nilai-nilai dan yang terkandung dalam Pancasila dan UUD NRI 1945. Usaha

\footnotetext{
12 Barda Nawawi Arief, Beberapa Aspek Pengembangan Ilmu Hukum Pidana - Pidato Pengukuhan Guru Besar Ilmu Hukum Pidana (Penerbit Pustaka Magister 2015)13.

13 Nyoman Sertikat Putra Jaya, Pembaharuan Hukum Pidana (Pustaka Rizki Putra 2017) 2.
} 
pembaharuan hukum pidana agar didasarkan pada politik hukum pidana dan politik kriminal yang mencerminkan aspirasi nasional serta kebutuhan masyarakat dewasa ini dan pada masa yang akan datang dapat berkomunikasi dengan perkembangan hukum dalam dunia yang maju. ${ }^{14}$

a. Sejauh mana efektivitas ketentuan undang-undang pidana (umum dan khusus) yang dipakai sekarang.

b. Hukum pidana adat dan agama yang hidup dalam masyarakat Indonesia, serta;

c. Keinginan yang mendasar dalam masyarakat Indonesia yang beranekaragam, terutama untuk menentukan asas-asas/prinsipprinsip hukum pidana Indonesia yang tepat, termasuk materi pokoknya yang memerlukan pengaturan dalam hukum pidana yang akan datang.

Maka dengan adanya usaha pembaharuan yang politik hukum pidana atau kebijakan hukum pidana yang berlandaskan Pancasila dan UUD NRI 1945, haruslah peraturan tersebut memuat peraturan yang membatasi tindakan-tindakan yang tidak hanya sebatas mengatur tingkah laku yang benar-benar dilarang baik perbuatan dan akibatnya, namun juga perbuatan yang melanggar nilai ke-Tuhanan dan moral yang hidup dalam masyarakat yang terkandung dalam Pancasila sebagai sumber segala sumber hukuum.

Perkembangan globalisasi dan perbuatan modernisasi serta budaya barat yang datang dan masuk ke
Indonesia, dapat menggerus nilai-nilai Pancasila. Seharusnya perbuatanperbuatan modernisasi dan globalisasi selayaknya dapat ditangkal dengan dibuatnya peraturan-peraturan yang dapat membatasi perbuatan yang bertentangan dengan nilai-nilai Pancasila dan nilai moral yang hidup dalam masyarakat. Salah satu perbuatan yang diakibatkan perkembangan zaman yang bertentangan dengan Pancasila adalah perbuatan LGBT. Selama ini perbuatan LGBT berlindung atas nama HAM yang universal yang dianut negara-negara barat, sedangkan Indonesia menganut HAM yang Pancasila karena Pancasila sudah menganut nilai-nilai kemanusiaan. Hal tersebut dapatlah dilihat dari nilai-nilai keseimbangan yang terdapat dalam Pancasila yang bersumber dari jiwa bangsa.

Nilai kemanusiaan yang dimiliki Pancasila tidak boleh bertentangan dengan nilai ke-Tuhanan. Pada perjalanannya kebijakan hukum pidana harusnya mampu menjaga nilainilai yang suci dari Pancasila dari perbuatan-perbuatan yang bertentangan dengan nilai keseimbangan Pancasila itu sendiri, salah satunya adalah perbuatan LGBT tersebut. Perbuatan LGBT menjadi perbuatan yang sangat bertentangan dengan Pancasila dan seharusnya tidak ada toleransi atas nama HAM yang universal yang tidak mengindahkan Pancasila sebagai sumber dari segala sumber hukum.

Kebijakan hukum pidana seharusnya mampu menanggulangi LGBT dengan membuat atau 
merekonstruksi suatu peraturan yang baik yang dapat menjadi upaya menanggulangi perbuatan yang bertentangan dengan Pancasila dan nilai-nilai moral masyarakat tersebut yang terkandung dalam tiga nilai keseimbangan Pancasila. Perbuatan LGBT juga membuat kegaduhan dalam masyarakat dan menimbulkan pandangan buruk dari masyarakat. Kebijakan hukum pidana atau politik hukum pidana harusnya dapat melindungi ketertiban dan menjaga keseimbangan dalam masyarakat. Kebijakan hukum pidana juga harus memikirkan tindakan, sifat melawan hukum dari perbuatan tersebut, dan tujuan pemidanaan terhadap suatu perbuatan yang akan dikenai sanksi pidana tersebut. Perbuatan LGBT dipandang melanggar sifat melawan hukum yang materil karena tidak sesuai dengan nilai-nilai yang hidup dimasyarakat dan menimbulkan keresahan dan dapat dianggap sebagai tindak pidana. Tindak pidana harus dipandang sebagai gangguan terhadap keseimbangan, keselarasan dan keserasian dalam kehidupan masyarakat. 15

Perbuatan LGBT sudah dianggap sebagai perbuatan yang memberikan gangguan keseimbangan, keselarasan dan keserasian dalam masyarakat, serta menimbulkan kegaduhan dan ketakutan akan terikut dalam perbuatan tersebut. Namun dalam arah politik hukum pidana kedepannya diharapkan dapat menanggulangi perbuatan LGBT dengan hukum pidana, dan disesuaikan dengan pemidanaan dan tujuan hukum pidana agar menjadi efektif dan dapat menganggulangi perbuatan LGBT tersebut. Karena telah dianggap sebagai suatu tindak pidana dalam prespektif Pancasila dan nilainilai yang hidup dalam masyarakat ada baiknya LGBT segera ditanggulangi dengan mengarahkan kebijakan hukum pidana.

Beberapa kasus LGBT sudah terjadi di Indonesia namun tidak ada hukum positif yang terlanggar secara pasti menyebtukan tindakan LGBT dan hanya mendekati perbuatan tersebut yang tersebut dalam delik salah satunya pasal 292 KUHP, akibat belum adanya upaya kebijakan hukum pidana dalam menanggulangi perbuatan tersebut. Pasal 292 KUHP juga menyebutkan tindakan seksual sesama kelamin atau sejenis namun tidak bisa menjerat pelaku LGBT karena perbuatan tersebut harus dilakukan terhadap anak dibawah umur. Pasal 292 KUHP berbunyi:

...."orang yang cukup umur, yang melakukan perbuatan cabul dengan orang lain sama kelamin, yang diketahui atau sepatutnya harus diduga, bahwa belum cukup umur, diancam dengan pidana penjara paling lama lima tahun".

Beberapa pelaku akhirnya hanya dibebaskan karena tidak dapat dijerat pidana dan tidak dapat dijerat dengan Pasal 292 KUHP. Karena secara detail perbuatan tersebut tidak perbuatan LGBT, namun dianggap perbuatan sodomi. Namun perbuatan LGBT itu sesungguhnya sudah menciderai nilainilai keseimbangan Pancasila dan nilai-

15 Muladi, Proyeksi Hukum Pidana Materil Indonesia Di Masa Datang (Pidato Pengukuhan Guru Besar Ilmu Hukum Pidana 1990) 10. 
nilai moral yang ada dalam masyarakat serta mendekati perbuatan pornografi. Ada baiknya tindakan LGBT ini dirumuskan dalam undang-undang pornografi dengan melakukan perluasan makna serta penjelasan dari Pasal 292 KUHP serta Pasal 10 undangundang pornografi. Perluasan makna tersebut dapat memberikan tambahan untuk merumuskan Pasal 292 a KUHP juga Pasal 10 ayat (2) dan (3) UU Pornografi, yang menurut penulis rumusan pasal berisikan seperti sebagai berikut:

Pasal 292 a KUHP ..." Setiap orang yang melakukan perbuatan zina dengan orang lain sama kelamin, serta tindakan melanggar kesusilaan yang bertentangan dengan nilai ke-Tuhanan Pancasila, serta nilai kesusilaan yang hidup di masyarakat, diancam dengan pidana penjara paling lama lima tahun"

Serta Pasal 10 ayat (2) dan ayat (3) Undang-Undang nomor 44 Tahun 2008 Tentang Pornografi memiliki rumusan berbunyi seperti demikian berikut ini:

..."Setiap orang dilarang mempertontonkan diri atau orang lain dalam pertunjukan atau di muka umum yang menggambarkan perbuatan pelanggaran kesusilaan yang dilakukan dengan orang lain sama kelamin yang bertentangan dengan nilai ke-Tuhanan Pancasila serta nilai kesusilaan yang hidup di masyarakat"

dan ayat (3) berbunyi:

..."setiap orang dilarang mempertontonkan diri atau orang lain dalam pertunjukan atau di muka umum, yang menggambarkan persenggama-an, perbuatan seksual, eksploitasi seksual, atau yang bermuatan pornografi lainya yang dilakukan dengan orang lain sama kelamin".

Namun dapat pula dirumuskan atau direkonstruksikan dalam Pasal
484 ayat (1) Rancangan KUHP, dengan menambah satu huruf yang awal berbunyi:

"Dipidana karena zina, dengan pidana penjara paling lama 5 (lima) tahun:

a. laki-laki yang berada dalam ikatan perkawinan melakukan persetubuhan dengan perempuan yang bukan istrinya;

b. perempuan yang berada dalam ikatan perkawinan melakukan persetubuhan dengan laki-laki yang bukan suaminya;

c. laki-laki yang tidak dalam ikatan perkawinan melakukan persetubuhan dengan perempuan, padahal diketahui bahwa perempuan tersebut berada dalam ikatan perkawinan;

d. perempuan yang tidak dalam ikatan perkawinan melakukan persetubuhan dengan laki-laki, padahal diketahui bahwa laki-laki tersebut berada dalam ikatan perkawinan; atau

e. laki-laki dan perempuan yang masing-masing tidak terikat dalam perkawinan yang sah melakukan persetubuhan.

Dengan menambah rancangan dalam pasal tersebut huruf $f$ yang berbunyi

... "laki-laki yang dalam ikatan perkawinan atau tidak dalam ikatan perkawinan melakukan persetubuhan dengan sama kelamin",

huruf g yang berbunyi

.... "perempuan yang dalam ikatan perkawinan atau tidak dalam ikatan perkawinan melakukan persetubuhan dengan sama kelamin",

serta huruf $h$ yang berbunyi

.... "Setiap orang yang melakukan perbuatan zina dengan orang lain sama kelamin, serta tindakan melanggar kesusilaan yang bertentangan dengan nilai ke-Tuhanan Pancasila, serta nilai kesusilaan yang hidup di masyarakat". 
Secara jelas perbuatan LGBT harus dirumuskan dengan pasti mengandung unsur perbuatan sesama jenis atau dengan sejenis alat kelamin tidak hanya terhadap anak dibawah umur. Perbuatan ini sebaiknya dirumuskan dalam undang-undang pornografi dan juga dalam rancangan KUHP seperti yang telah direkonstruksi seperti pada Pasal 10 ayat (2) dan (3) dan Pasal 484 ayat (1) huruf f, g, dan h karena tindakan ini adalah salah satu tindakan yang berorientasi pada seksualitas dan seksualitas yang dilakukan oleh sesama jenis, dan untuk ketentuan pidana di ikuti sesuai Pasal ketentuan pidana untuk Pasal 10 Undang-Undang Pornografi. Pembaharuan hukum pidana dengan kebijakan hukum pidana terhadap LGBT ini juga dapat dilakukan dengan pendekatan perbandingan atau komparatif. Pendekatan komparatif digunakan untuk mendapatkan masukan dalam penyusunan/ perumusan "ketentuan pidana" yang lebih operasional di waktu yang akan datang. ${ }^{16}$

Perbuatan LGBT juga sering dianggap sebagai penyakit yang menular, untuk itu selain merumuskan dengan baik perbuatan itu sebagai tindak pidana dengan kebijakan hukum pidananya, namun juga harus disertai dengan tujuan pemidanaan yang dapat menanggulangi perbuatan tersebut yang juga berorientasi pada perbaikan dan pengobatan terhadap pelaku. Tidak hanya mengedepankan suatu tindakan pembalasan yang menjadi tujuan dari teori pemidanaan retributif. Kebijakan hukum pidana pada dasarnya mempelajari masalah bagaimana sebaiknya hukum pidana itu dibuat, disusun dan digunakan untuk mengatur/mengendalikan tingkah laku manusia, khususnya untuk menanggulangi kejahatan dalam rangka melindungi dan mensejahterakan masyarakat. 17

Dengan demikian, maka tujuan pemidanaan adalah untuk memperbaiki kerusakan baik yang bersifat individual, maupun yang bersifat sosial (individual and social damages) yang diakibatkan oleh tindak pidana. Tujuan pemidanaan harus berorientasi pada pandangan yang integratif, yang terdiri dari seperangkat tujuan pemidanaan yang harus dipenuhi, dengan catatan bahwa, tujuan manakah yang merupakan titik berat sifatnya kasuistis. ${ }^{18}$ Seperti kasus LGBT, tujuan pemidanaan diarahkan kepada perbuatan si pelaku juga demi perbaikan diri pelaku LGBT sendiri. Seperti yang dilakukan dengan rancangan KUHP yang akan datang, tim perancang konsep KUHP Nasional telah sepakat bahwa tujuan pemidanaan adalah: 19

1. Mencegah dilakukannya tindak pidana dalam menegakkan norma hukum demi pengayoman masyarakat;

2. Memasyarakatkan terpidana dengan mengadakan pembinaan sehingga menjadikannya orang yang baik dan berguna;

16 Barda Nawawi Arief, Kebijakan Formulasi Ketentuan Pidana Dalam Peraturan Perundang-Undangan (Pustaka Magister 2016) 3.

17 Barda Nawawi Arief, Op.Cit, 8.

18 Ibid, 11.

19 Ibid. 
3. Menyelesaikan konflik yang ditimbulkan oleh tindak pidana, memulihkan keseimbangan dna mendatangkan rasa damai dalam masyarakat;

4. Membebaskan rasa bersalah pada terpidana.

Di sinilah harusnya arah politik hukum pidana atau kebijakan hukum pidana dalam menanggulangi perbuatan LGBT, dengan menitik beratkan pada tujuan pemidanaan yang dapat memberikan perbaikan dan pembinaan serta dapat membuat efek jera pada pelaku perbuatan LGBT, serta mengembalikan keseimbangan, keselarasan dan keserasian dalam masyarakat, dan menjaga kesucian nilai-nilai keseimbangan yang ada pada Pancasila terutama nilai ke-Tuhanan. Kebijakan hukum pidana dalam menanggulangi perbuatan LGBT diarahkan juga untuk membina pelaku agar kembali dapat diterima dalam masyarakat yang beradab dan mendapatkan kesembuhan selain mendapatkan pemidanaan. Karena perbuataan ini dianggap sebagai penyakit yang dapat menular melalui pergaulan.

\section{Kajian Perbandingan}

Terdapat banyak negara di dunia yang melarang serta mengkecam perbuatan LGBT ini. Tidak hanya dalam bentuk propaganda namun juga beberapa negara merumuskan ketentuan pidana dalam beberapa pasal dalam penal code nya. Negara-negara yang melarang perbuatan LGBT tersebut dengan beberapa alasannya. Antara lain, melanggar keagamaan, melanggar moral, serta perbuatan tersebut dianggap menjijikkan karena perbuatan seksualitas sesama jenis.

Negara Arab Saudi adalah negara yang sangat menentang tindakan perbuatan LGBT. Arab saudi berpegang pada hukum agama yaitu berdasarkan Al-Qur'an dan Hadist. Arab Saudi menghukum pelaku LGBT dengan hukuman rajam atau dengan cara dilempari dengan batu sampai mati, karena perbuatan ini sudah melanggar apa yang dikehendaki dalam Al-Qur'an juga Hadist.

Di Mauritania, LGBT juga adalah perbuatan ilegal dan hukumannya pun sama dengan Arab Saudi. Sebelum kemerdekaan Mauritania pada tahun 1960, homoseksualitas hanya dapat dihukum 3 tahun penjara. Pada tahun 1980 Mauritania memperoleh kemerdekaan dan hukum pidana diubah. Pada tahun 1983 untuk memasukkan hukum Syariah, yang membuat LGBT menjadi kejahatan terhadap kehendak ilahiah Al Qur'an dan dapat dihukum mati. Menurut KUHP Mauritania:

Pasal 308:20

20 Terjemahan Mauritania Penal Code Article 308 and 306 "Any adult Muslim who has committed an indecent act or an act against nature with an individual of the same sex will be punished to death by public stoning. If the act is between two women, they will be punished by the punishment established in paragraph one of Article 306."

Article 306:

"Any person who has committed an outrage against public decency and Islamic morals or has desecrated sacred places or has helped to desecrate them... will be punished by a correctional punishment of three months to two years and a fine of 5,000 to 60,000 UM." 
..."Setiap Muslim dewasa yang telah melakukan tindakan tidak senonoh atau tindakan melawan alam dengan individu dari jenis kelamin yang sama akan dihukum sampai mati dengan rajam publik. Jika tindakan tersebut di antara dua wanita, mereka akan dihukum dengan hukuman yang ditetapkan pada ayat satu dari Pasal 306."

Pasal 306 :

..."Setiap orang yang telah melakukan kemarahan terhadap kesopanan dan moral Islam atau telah menajiskan tempat-tempat suci atau telah membantu menajiskan mereka ... akan dihukum dengan hukuman pemasyarakatan tiga bulan sampai dua tahun dan denda 5.000 sampai 60.000 UM."

LGBT juga menjadi perbuatan yang ilegal di Guinea. Pasal 325 KUHP Guinea mengkriminalkan aktivitas sesama jenis:

Ayat 3: Serangan tidak senonoh

Pasal $325: 21$

..."Siapa pun yang melakukan tindakan yang cabul atau bertentangan dengan alam dengan individu dari jenis kelamin yang sama akan dihukum 6 bulan - 3 tahun penjara dan denda antara 100.000 - 1.000.000 franc Guinea. Jika tindakan tersebut dilakukan dengan anak di bawah usia 21 tahun, hukuman maksimal akan ditegakkan. Jika tindakan ini dilakukan atau dilakukan dengan kekerasan, pihak yang bersalah akan dikenai hukuman penjara selama jangka waktu antara 5 dan 10 tahun."
Tindakan ini dilakukan Guinea karena tidak sesuai dengan kodrat manusia yang hidup berpasang-pasangan.

Salah satu Negara ASEAN yang juga memberikan hukuman serta memasukkan perbuatan LGBT sebagai tindak pidana yang dapat dihukum adalah Singapura. Singapura dalam Pasal 377A KUHPnya melarang perbuatan tersebut. Bagian 377A dari KUHP Singapura adalah bagian utama dari undang-undang yang melarang hubungan seks antara orang dewasa yang saling menyetujui.

Bagian 377A ("Kejahatan Asusila") menyatakan bahwa:22

..."Setiap laki-laki yang, di depan umum atau tertutup, melakukan, atau menjalankan perintah, atau mendapatkan atau mencoba untuk mendapatkan komisi (tindakan seksual) oleh laki-laki manapun, setiap tindakan kasar terhadap orang lain, akan dihukum penjara untuk masa hukuman yang bisa berlanjut hingga 2 tahun."

\section{PENUTUP}

Berdasarkan pembahasan dan analisis di atas, dapat diambil kesimpulan sebagai berikut: perbuatan LGBT sejatinya telah merusak serta menentang nilai-nilai keseimbangan yang ada dalam Pancasila sebagai wujud jiwa dan moral dari masyarakat

21 Terjemahan Guinea Penal Code Article 325 "Anyone who commits an act that is obscene or against nature with an individual of the same sex will be punished by 6 months -3 years imprisonment and a fine of between $100,000-1,000,000$ Guinean francs. If the act is committed with a minor younger than 21 years of age, the maximum penalty will be enforced. If this act is consummated or attempted with violence, the guilty party will be subjected to a punishment of imprisonment for a term of between 5 and 10 years."

22 Terjemahan Singapore Penal Code Section 377A "Any male person who, in public or private, commits, or abets the commission of, or procures or attempts to procure the commission by any male person of, any act of gross indecency with another male person, shall be punished with imprisonment for a term which may extend to 2 years. 
Indonesia, terutama nilai ke-Tuhanan. Oleh karena Indonesia adalah negara berke-Tuhanan seharusnya tindakan yang menentang dengan nilai keTuhanan dapat dipidana melalui kebijakan hukum pidana dengan memperhati-kan pula tujuan dari pemidanaan tersebut.

Berdasarkan kesimpulan di atas, dapat disampaikan saran sebagai berikut : Kebijakan hukum pidana amat penting untuk melindungi dan menjaga kesucian nilai ke-Tuhanan Pancasila untuk itu diperlukan kebijakan hukum dalam menanggulangi perbuatan LGBT tersebut, dengan memanfaatkan kajian perbandingan.

\section{DAFTAR BACAAN}

\section{Buku}

Al-Qur'an, Tafsir dan Terjemahan AlQur'an (Pustaka Al-Mubin 2017).

Arief, Barda Nawawi, Bunga Rampai Kebijakan Hukum Pidana Perkembangan Penyusunan Konsep KUHP Baru (Prenada Media 2014).

-----, Beberapa Aspek Pengembangan Ilmu Hukum Pidana (Pidato Pengukuhan Guru Besar Ilmu Hukum Pidana) (Penerbit Pustaka Magister 2015).

-----, Pembangunan Sistem Hukum Nasional (Indonesia) (Penerbit Pustaka Magister 2015).

-----, Kumpulan Hasil Seminar Hukum Nasional Ke I s/d IX dan Konvensi Hukum Nasional 2008 Tentang Undang-Undang Dasar 1945 Sebagai Landasan Konstitusional Grand Design Sistem dan Politik
Hukum Nasional (Badan Penerbit Universitas Diponegoro 2016).

, Kebijakan Formulasi Ketentuan Pidana Dalam Peraturan PerundangUndangan (Pustaka Magister 2016).

Effendi, Masyhur, Dimensi Dan Dinamika Hak Asasi Manusia Dalam Hukum Nasional Dan Internasional (Ghalia Indonesia 1994).

Jaya, Nyoman Sertikat Putra, Pembaharuan Hukum Pidana (Pustaka Rizki Putra 2017).

Muladi, Proyeksi Hukum Pidana Materil Indonesia Di Masa Datang (Pidato Pengukuhan Guru Besar Ilmu Hukum Pidana 1990).

Prasetyo, Teguh, Sistem Hukum Pancasila (Sistem, Sistem Hukum dan Pembentukan Peraturan Perundang-undangan di Indonesia, Perspektif Teori Keadilan Bermartabad (Nusa Media 2016).

Rahayu, Hukum Hak Asasi Manusia Semarang (Badan Penerbit Universitas Diponegoro 2015).

\section{Jurnal}

Soponyono, Eko, 'Kebijakan Kriminalisasi "Kumpul Kebo", Dalam Pembangunan Hukum Pidana Indonesia' (2013) 42 Jurnal Masalah-Masalah Hukum, 2.

Susilowati, Christina Maya Indah, 'Pancasila Sebagai Sumber Segala Sumber Hukum Dan Kekerasan Atas Nama Agama Di Indonesia' (2016) 45 Jurnal Masalah-Masalah Hukum, 2. 